\title{
Tsoong induces apoptosis and inhibits proliferation, migration and invasion of pancreatic ductal adenocarcinoma cells
}

\author{
YUN-PENG LUAN ${ }^{1}$, QI-FENG LI ${ }^{2}$, SHI-GUO WU ${ }^{2}$, DE-CHANG MAO ${ }^{1}$, \\ YAN-YUN DENG ${ }^{1}$ and RONG-WANG CHEN ${ }^{1}$ \\ ${ }^{1}$ College of Life Sciences, Southwest Forestry University, Kunming, Yunnan 650224; \\ ${ }^{2}$ Basic Medical College, Yunnan University of Traditional Chinese Medicine, Kunming, Yunnan 650500, P.R. China
}

Received October 8, 2016; Accepted October 4, 2017

DOI: $10.3892 / \mathrm{mmr} .2017 .8328$

\begin{abstract}
The roots of Codonopsis cordifolioidea (classified as campanulaceae cordifolioidea), locally known as Tsoong, have been used as a tonic food. The major components isolated from Tsoong have been demonstrated to present anti-human immunodeficiency virus-1 activities and cytotoxicity against various tumor cell lines. However, the possible effects of the novel compound isolated from Tsoong, cordifoliketones A, on pancreatic ductal adenocarcinoma (PDAC) cells, are still unknown. In the present study, cordifoliketones A extractions were prepared from Tsoong, and the possible effects on PDAC cell growth, apoptosis, migration and invasion in vitro and in vivo were exlored. The cytotoxicity assay, apoptosis assay, western blotting, migration and invasion assay, and a PDAC cell (AsPC-1, BxPC-3 and PANC-1) xenograft mice model were employed. The results demonstrated that treatment with cordifoliketones A: i) inhibited proliferation and promoted apoptosis of PDAC cells; ii) significantly induced apoptosis and altered expression of apoptosis-associated proteins in a dose-dependent manner; iii) suppressed migration and invasion of PDAC cells in a dose-dependent manner; and iv) restrained the growth of PDAC neoplasm in nude mice. Furthermore, cordifoliketones A demonstrated non-cytotoxic activity in a panel of normal human cells, including hTERT-HPNE, 293, hepatocyte HL-7702 and HL-1 cells. Therefore, these data indicated that cordifoliketones A may be a potential candidate compound for the prevention of PDAC cell proliferation and metastasis, presumably by induction apoptosis and inhibiting viability, invasion and migration of PDAC cells.
\end{abstract}

Correspondence to: Dr Yun-Peng Luan, College of Life Sciences, Southwest Forestry University, 300 Panlong Community Bailongsi, Kunming, Yunnan 650224, P.R. China

E-mail: luanyunpeng2015@126.com

Key words: Tsoong, cordifoliketones A, pancreatic ductal adenocarcinoma, apoptosis, proliferation, migration, invasion

\section{Introduction}

Pancreatic ductal adenocarcinoma (PDAC) is the most common pancreatic neoplasm, and is highly aggressive and malignant with a very low survival rate. Nowadays, as a devastating disease, PDAC is the fourth most common disease-associated mortality worldwide $(1,2)$. The 5 -year survival rate is $\sim 6 \%$, and only $20 \%$ of patients present with resectable disease $(3,4)$. The high mortality of these patients is partly due to more than three-quarters of the cases being diagnosed at too late a stage to allow surgical resection, which is the only curative option. Non-surgical patients are treated with standard chemotherapies (5). Despite numerous promising novel therapies approved by the Food and Drugs Administration, the advances have been very slow for patients with PDAC (6). In addition, some cancer cells can become progressively resistant to drugs during the course of treatment, ultimately resulting in a non-responsive tumor to chemotherapies (7). Therefore, novel effective therapeutic methods are necessary.

Traditional Chinese medicine is appreciated for its 5000-year-old history and still holds an important position in primary health care in China; it has also become more popular among cancer patients in the western world (8). Recent reports also demonstrated that Chinese herbs may be used for the development of functional foods, the promotion of health, and as pharmaceutical agents for various kinds of human cancers, such as oral, gastric, breast and epithelial ovarian cancers (9-13).

Codonopsis (Campanulaceae, C.) is represented in China by 39 species, some of which are commonly used as herbal remedies due to their tonic effects, such as $C$. pilosula and C. tangshen (14). In addition, the roots of some Codonopsis species, including $C$. cordifolioidea, C. bulleyana, $C$. micrantha and C. subglobosa, are well-known vegetables in southwest China $(15,16)$. Codonopsis cordifolioidea (C. cordifolioidea) is herbaceous plant found in Yunnan, Tibet, and Sichuan Provinces. Its roots, locally known as Tsoong, have been used as a food in Yunnan Province since ancient times (13). Meanwhile, this species has become an important economic plant widely cultivated in several areas of Yunnan Province $(17,18)$. As major components isolated from C. cordifolioidea, phenylpropanoids, lignans and flavonoids are isolated and demonstrated to present biological effects of 
anti-human immunodeficiency virus type 1 (HIV-1) activities and cytotoxicity $(13,19)$. Hu et al $(13)$ have performed and finished the isolation, structural elucidation and biological activities assessing of the major compounds, termed cordifoliketones A-B. The cytotoxicity tests for the isolates were performed in HL-60 (human acute promyelocytic leukemia), Hep-G2 (human hepatocellular carcinoma), KB (human oropharyngeal epidermoid carcinoma) and MDA-MB-231 (human breast cancer cells) tumor cell lines. Their results revealed that compounds 1-2 have significant potential cytotoxic abilities against various tumor cell lines (13). However, the possible effects of these new compounds isolated from the roots of $C$. cordifolioidea, Tsoong, on the proliferation, apoptosis, migration and invasion ability of PDAC, are still unknown.

In present study, an extraction of cordifoliketones A from Tsoong was prepared, and the possible effects against PDAC cells was explored. The human PDAC cell lines, AsPC-1, BxPC-3 and PANC-1, were used. The cytotoxicity against PDAC cells and the effects of cordifoliketones A on PDAC cell proliferation, apoptosis, invasion and migration were examined in vitro and in vivo. The effect of cordifoliketones A treatment on the survival and apoptosis, invasion and migration of human PDAC cell in vitro, were evaluated by resazurin reduction assay, flow cytometry, and migration and invasion assays. Western blotting was also used to determine the expression of cytokine associated with apoptosis. A xenograft nude mouse model was established by injection with PDAC cells followed by treatment with cordifoliketones A.

On day 27 post treatment, mice were sacrificed, and tumors were isolated for determination of weight and volume.

\section{Materials and methods}

Preparation of cordifoliketones A. Tsoong, roots of $C$. cordifolioidea, were collected in Dali Prefecture and Yuxi (Yunnan, China) in September 2013. The identification of the plant material was verified by Professors Chen. and Mei (Yunnan Nationalities University). A voucher specimen (YNNI 09-9-13) was used. The air-dried and powdered roots of $C$. cordifolioidea $(1.5 \mathrm{~kg}$ ) were repeatedly subjected to column chromatography on Si gel, Sephadex LH-20, RP-18 and Preparative high-performance liquid chromatography systems to obtain a $70 \%$ aqueous methanol extract, which contained compounds 1-11,including two novel phenylpropanoids, termed cordifoliketones A-B, together with nine known phenylpropanoids (13). The combined extract was then stepwise eluted by petroleum, ethyl acetate and n-butyl alcohol (20). A total of $50 \mathrm{mg}$ phenylpropanoids, termed cordifoliketones A, was isolated and extracted by vacuum column chromatography at $20-25^{\circ} \mathrm{C}$. The combined phenylpropanoids were subjected to a silica gel (Merck KGaA, Darmstadt, Germany) vacuum liquid chromatography and eluted with $n$-hexane (Sigma-Aldrich; Merck KGaA; diameter, $6.5 \mathrm{~cm}$ ), chloroform (Sigma-Aldrich; Merck KGaA), EtOAc (Sigma-Aldrich; Merck KGaA), acetone (Sigma-Aldrich; Merck KGaA) and $\mathrm{MeOH}$ (Sigma-Aldrich; Merck KGaA) to obtain a major product. The product was then subjected to silica gel open column chromatography (diameter, $5 \mathrm{~cm}$ ) and eluted with $n$-hexane-EtOAc step gradients. Following this, 23 fractions of $200 \mathrm{ml}$ each were collected.
These fractions were then pooled into eleven new fractions (compounds 1-11). Nine of them were known phenylpropanoids as described previously (13). The novel phenylpropanoid, was crystallized from $n$-hexane to obtain colorless crystals and termed as cordifoliketones A. The physicochemical data cordifoliketone A are presented in Fig. 1A and described as followed: Obtained as pale yellow gum; UV (MeOH) $\lambda$ max ( $\log \varepsilon) 325$ (2.42), 288 (4.22), 248 (3.12), 210 (4.89) nm; IR (KBr) vmax 3376, 2925, 2850, 1713, 1638, 1512, 1450, 1434, $1362,1283,1175,1137,1086,1047,971,828 \mathrm{~cm}-1 ; 1 \mathrm{H}$ and $13 \mathrm{C}$ NMR data (C5D5N, 500 and $125 \mathrm{MHz}$, respectively); positive ESIMS m/z 249 [M+Na]+; HRESIMS m/z 249.0746 [M+Na]+ (calculated 249.0739 for molecular formula determined as $\mathrm{C} 11 \mathrm{H} 14 \mathrm{NaO} 5)$. The cordifoliketones $\mathrm{A}$ was prepared and dissolved in $0.2 \%$ ethanol $(\mathrm{v} / \mathrm{v})$ in the present study.

Cell culture. Human PDAC cell lines AsPC-1, BxPC-3 and PANC-1, the hTERT-HPNE and 293 normal human pancreatic cells, the HL-7702 hepatocyte cell line, and HL-1 cardiac myocytes were purchased from Cell Bank of the Chinese Academy of Sciences (Shanghai, China). PDAC cell lines and hTERT-HPNE cells were cultured in specific medium supplemented with $10 \%(\mathrm{v} / \mathrm{v})$ fetal bovine serum (FBS) and $1 \%$ antibiotics at $37^{\circ} \mathrm{C}$ in a humidified incubator under $5 \%$ $\mathrm{CO}_{2}$ (3). The HL-7702 cells were cultured in RPMI 1640 medium (Gibco; Thermo Fisher Scientific, Inc., Waltham, MA, USA) supplemented with $8 \%$ dialyzed FBS (Gibco; Thermo Fisher Scientific, Inc.) and 1\% penicillin/streptomycin (Gibco; Thermo Fisher Scientific, Inc.) as described previously (21). HL-1 cells were cultured in Claycomb medium supplemented with $10 \%$ FBS, 2 mM L-glutamine, $0.1 \mathrm{mM}$ norepinephrine, 100 units $/ \mathrm{ml}$ penicillin and $100 \mu \mathrm{g} / \mathrm{ml}$ streptomycin. The cells were cultured at $37^{\circ} \mathrm{C}$ and $5 \% \mathrm{CO}_{2}$. Twice a week, cells were split after reaching confluence. 293a cells were grown in Dulbecco's modified Eagle's medium supplemented with $10 \%$ FBS, $1 \%$ L-glutamine and $1 \%$ penicillin-streptomycin stock solutions. All of the cells were negative for: HIV-1, hepatitis B virus, hepatitis $\mathrm{C}$ virus as detected by quantitative polymerase chain reaction; mycoplasma using fluorescent monoclonal antibodies against major outer membrane protein; bacteria under microscopy without in medium antibiotics and varying $\mathrm{pH}$ values, yeast and fungi with a lack of hyphae with microscopy prior to experimentation by the Cell Bank of the Chinese Academy of Sciences (Shanghai, China).

Cytotoxicity assay. Resazurin reduction assay was performed to test the cytotoxic effects of the natural product, cordifoliketone A, on three PDAC cell lines (AsPC-1, BxPC-3 and PANC-1) and normal human cells (hTERT-HPNE, HL-7702, HL-1 and 293 cells) as described before $(22,23)$. The contribution of the extracts (at various tested concentrations, including $0,0.5,1,1.5,2,2.5,3,3.5,4,4.5,5,5.5$ and $6 \mu \mathrm{mol} / \mathrm{ml}$, respectively) to the fluorescence (Fs) was determined, both in the absence and presence of resazurin, prior to any cell studies. A total of $2 \times 10^{4}$ cells/well were seeded in 96-well plates in a total volume of $100 \mu \mathrm{l}$. Cordifoliketone A of varying concentrations $(0-6 \mu \mathrm{mol} / \mathrm{ml})$ or the positive control Doxorubicin $(3.5 \mu \mathrm{mol} / \mathrm{ml})$, was immediately added to additional $100 \mathrm{ml}$ of culture medium to obtain a total volume of $200 \mu \mathrm{l} /$ well, respectively. After 24 h or 48 h, $20 \mathrm{ml}$ resazurin (Sigma-Aldrich, 
A<smiles>[R]O[C]C(=O)c1cc(OC)c(OC)cc1O</smiles>

B

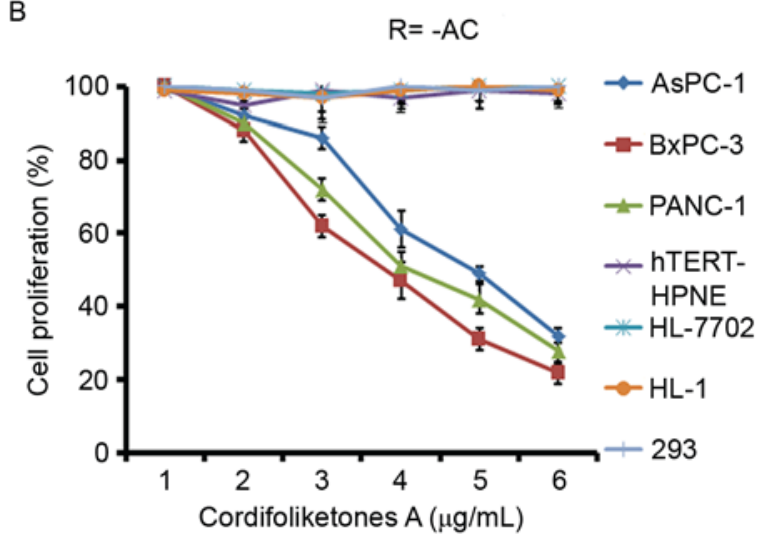

C

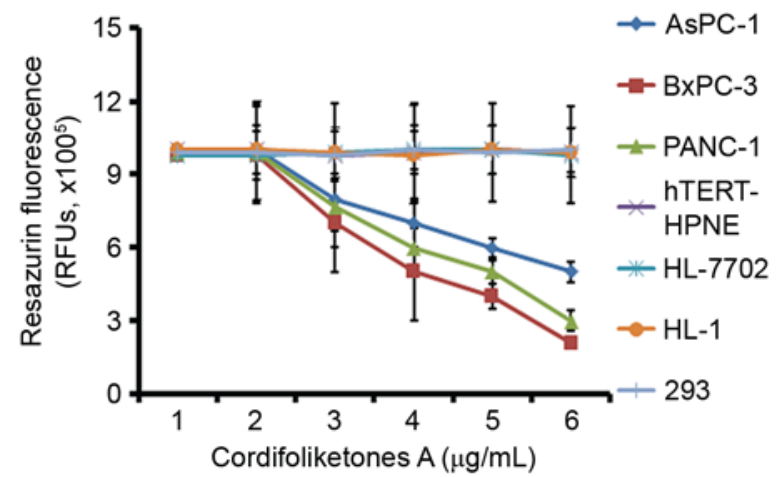

Figure 1. Cordifoliketones A inhibits proliferation of different PDAC cell lines. (A) The structure of cordifoliketones A extracted from the roots of C. cordifolioidea, Tsoong. -Ac, acetyl (CH3CO-). (B) Dose effect of cordifoliketones A treatment on the proliferation of three PDAC cell lines (AsPC1, BxPC-3 and PANC-1), and normal human cell lines. The cell number at each cordifoliketones A concentration is represented as a percentage of control. Average values are from three independent experiments performed in six replicates. (C) Fluorescence signal screening assay in cells treated with different doses of cordifoliketones A. Data are presented as the mean \pm standard deviation $(\mathrm{n}=3) .{ }^{\#} \mathrm{P}<0.05$ vs. hTERT-HPNE; ${ }^{\# \#} \mathrm{P}<0.05$ vs. HL-7720 cells; ${ }^{* *} \mathrm{P}<0.05$ vs. HL-1 cells; ${ }^{*} \mathrm{P}<0.05$ vs. 293 cells. PDAC, pancreatic ductal adenocarcinoma.

Merck $\mathrm{KGaA}$ ) $0.01 \% \mathrm{w} / \mathrm{v}$ in $\mathrm{ddH}_{2} \mathrm{O}$ was added to each well and the plates were incubated at $37^{\circ} \mathrm{C}$ for $4 \mathrm{~h}$. Blank control were

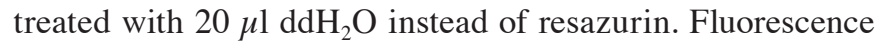
was measured on a microplate reader using an excitation wavelength of $544 \mathrm{~nm}$ and an emission wavelength of $590 \mathrm{~nm}$. Doxorubicin was used as positive control. After $72 \mathrm{~h}$ incubation and staining by resazurin (Sigma-Aldrich, Merck $\mathrm{KGaA}$ ), Fs was measured on a microplate reader (Bio-Rad Laboratories, Inc., Hercules, CA, United States) using an excitation wavelength of $544 \mathrm{~nm}$ and an emission wavelength of $590 \mathrm{~nm}$. Each assay was performed at least three times, with six replicates each. Half-maximal inhibitory concentration $\left(\mathrm{IC}_{50}\right)$ values represent the sample concentration required to inhibit $50 \%$ of cell proliferation, and was calculated from a calibration curve by linear regression as described previously (24). The calculation formula was as follows: Percentage (\%) of cell proliferation $=(\mathrm{Fs}$ of cells treated with cordifoliketone A/Fs of untreated cells) $\times 100$.

Apoptosis assay. A propidium iodide (PI) and Annexin V-fluorescein isothiocyanate-flow cytometry assay (BD Pharmingen; BD Biosciences, Franklin Lakes, NJ, USA) was used to detect the apoptosis rate in the AsPC-1, BxPC-3 and PANC-1 cells after treatment with various concentrations of cordifoliketones A $(0,2,4$ or $6 \mu \mathrm{g} / \mathrm{ml})$. In the $0 \mu \mathrm{mol} / \mathrm{ml}$ cordifoliketones A group, cells were treated with $0.2 \%$ ethanol. Briefly, $1 \times 10^{6}$ cells per well were cultured in 6-well plates in the absence of $10 \%$ FBS for $48 \mathrm{~h}$. Adherent cells were detached with $0.25 \%$ trypsin without EDTA in $1 \mathrm{X}$ PBS. Cells were harvested in complete RPMI 1640 medium and centrifuged at $350 \mathrm{x} \mathrm{g}$ for $5 \mathrm{~min}$. According to the manufacturer's protocol, each of the cells were washed with $1 \mathrm{X}$ PBS and then stained with $50 \mathrm{ug} / \mathrm{ml} \mathrm{PI}$ and Annexin V-FITC at $25^{\circ} \mathrm{C}$ for $30 \mathrm{~min}(25)$.

Detection of apoptosis-associated proteins by western blotting. The present study used western blotting to evaluate the protein expression levels of caspase-3, caspase-8, caspase-9, Bad, Bax, Bcl-2 and Bcl-xL in PDAC cell lines. Antibodies for caspase-3 (sc-271759), caspase-8 (sc-5263), caspase-9 (sc-17784), Bad (sc-8044), Bax (sc-20067), Bcl-2 (sc-509), Bcl-xL (sc-136207) and GAPDH (sc-69778) were purchased from Santa Cruz Biotechnology, Inc. (Dallas, TX, USA). According to the manufacturer's protocols, $\sim 40 \mathrm{mg}$ total cell lysate protein [quantified with a Bicinchoinic Acid Protein Assay kit (Beyotime Institute of Biotechnology, Shanghai, China)] extracts from each cell line were separated using $15 \%$ SDS-PAGE and transferred to nitrocellulose membranes (Beyotime Institute of Biotechnology). The membrane was blocked with PBS containing 0.05\% Tween-20 (PBST; (Beyotime Institute of Biotechnology,) with $10 \%$ nonfat dry milk (Beyotime Institute of Biotechnology) overnight at $4^{\circ} \mathrm{C}$ for $12 \mathrm{~h}$ and subsequently washed three times for $10 \mathrm{~min}$ each time. The membrane was incubated with monoclonal anti-Bax (1:500), anti-Bcl-2 (1:200), anti-Bcl-xL (1:800), anti-Bad (1:800), and polyclonal anti-caspase-3 (1:1,000), -8 (1:200), and -9 (1:500) antibodies at $4^{\circ} \mathrm{C}$ for $24 \mathrm{~h}$. Following three washes three times for $10 \mathrm{~min}$ each, the membrane was incubated with a horseradish-peroxidase conjugated rabbit anti-mouse IgG (1:2,500; Beyotime Institute of Biotechnology, A0216) for $2 \mathrm{~h}$ at room temperature, and washing three times for $10 \mathrm{~min}$ each time. Then the membrane was developed in enhanced 
chemiluminescence-based detection (GE Healthcare, Chicago, IL, USA) as previously described (25). The optical densities of the protein bands for the target proteins were analyzed for each group in order to semi-quantity the protein levels $(26,27)$.

Cell migration and invasion assay. The present study determined the possible effect of cordifoliketones A on the viability of PDAC cells. Following this, the effect of cordifoliketones A on proliferation of PDAC cells in vivo was also detected. BioCoat Matrigel invasion chambers (BD Biosciences) were used to compare the effect of cordifoliketones A treatment on in vitro invasion of AsPC-1, BxPC-3 and PANC-1 cells, according to the manufacturer's protocol. Briefly, for the invasion assay, Costar Transwell 8- $\mu \mathrm{m}$ inserts were coated with $50 \mu \mathrm{g}$ reduced serum Matrigel (BD Biosciences). Invasion chambers were coated with Matrigel. AsPC-1, BxPC-3 and PANC-1 cells $\left(1 \times 10^{6}\right)$ were treated with various concentrations of cordifoliketones $\mathrm{A}(0.2 \%$ ethanol): $0,2,4$ or $6 \mu \mathrm{g} / \mathrm{ml}$ were added per chamber.

Dulbecco's modified Eagle's medium (BD Biosciences) supplemented with $10 \%$ FBS was used in the lower chamber. Following incubation, the cells that had invaded through the membrane were fixed with polyoxymethylene at $25^{\circ} \mathrm{C}$ for $30 \mathrm{~min}$ (Sigma-Aldrich, Merck KGaA) and stained with crystal violet (Sigma-Aldrich, Merck KGaA), at room temperature for $0.5 \mathrm{~h}$, before the membrane was removed and mounted on a slide for microscopic assessment. Invasive cells were visualized at $\mathrm{x} 40$ magnification under a light microscope (Leica Microsystems GmbH, Wetzlar, Germany) and the number of cells in five random fields was counted and the average calculated (average $=$ sum number of cells in five random fields/five). For migration assays, the same procedure was used excluding the Matrigel.

After $12 \mathrm{~h}$, non-invading cells and media were removed, and cells on the lower surface of the membrane were fixed with polyoxymethylene and stained with $0.1 \%$ crystal violet (both from Sigma-Aldrich; Merck KGaA) for $0.5 \mathrm{~h}$ at room temperature. Stained cells were counted under a microscope (Leica Microsystems GmbH, inverted microscope, DMI3000B) in five randomly selected fields, and the aforementioned average (as described above) was used to indicate cell migration and invasion. All experiments were performed in triplicate (8).

PDAC cells xenograft mouse model. A total of $36 \mathrm{BALB} / \mathrm{c}$ nude mice (female; age, 4-5 weeks; weight, 20-25 g; Beijing HFK Bioscience Co., Ltd., Beijing, China; animal license no. SCXK 2009-000) were housed and raised in the laboratory animal center of Yunnan University (Kunming, China). The mice were maintained in a $20-25^{\circ} \mathrm{C}$ quiet, $40-60 \%$ humidified vivarium under a $12 \mathrm{~h}$ light/dark cycle. They were allowed free access to water and food prior to experimentation. The treatment and use of animals during the study was approved by the Animal Ethics Committee of Yunnan University.

Mice were randomly assigned to 6 groups ( $\mathrm{n}=6 /$ group): Mice bearing human AsPC-1, BxPC-3 and PANC-1 cells alone (PDAC + placebo groups, control), as well as mice bearing human AsPC-1, BxPC-3 and PANC-1 cells and treatment with cordifoliketones A (PDAC + CA groups). In a preliminary experiment, different concentrations $(20,80,120$, and $240 \mathrm{M} / \mathrm{kg}$ ) of cordifoliketones A (ethanol extract, $80 \mathrm{M}$, supplied by Prof. Yu-Ming Chen of Shanghai Traditional
Table I. Cytotoxic effects of compounds on a variety of pancreatic ductal adenocarcinoma cells.

\begin{tabular}{lccc}
\hline & \multicolumn{3}{c}{ PDAC cell lines $\left(\mathrm{IC}_{50} \mu \mathrm{g} / \mathrm{ml}\right)$} \\
\cline { 2 - 4 } Compounds & AsPC-1 & BxPC-3 & PANC-1 \\
\hline Cordifoliketones A & $5.56 \pm 0.22$ & $4.26 \pm 0.11$ & $4.18 \pm 0.31$ \\
Doxorubicin $(\mu \mathrm{M})$ & $2.86 \pm 0.21$ & $2.69 \pm 0.14$ & $3.49 \pm 0.18$ \\
\hline
\end{tabular}

Values were expressed as means \pm standard deviation $(n=3)$.

Medical University, Shanghai, China) were used to assess the appropriate in vivo dose. $\mathrm{IC}_{50}$ values of cordifoliketones $\mathrm{A}$ in PANC-1 cells were the highest among the three PDAC cell lines in vitro. A volume of $100 \mu 1$ of PANC-1 cells suspended in PBS $\left(1.0 \times 10^{7} / \mathrm{ml}\right)$ were injected intradermally into the left axilla of the mice. On the following day, mice bearing PDAC-1 cells received $20,80,120$ or $240 \mathrm{M} / \mathrm{kg}$ cordifoliketones A or an equal volume noncytotoxic placebo ( $0.2 \%$ ethanol) treatment by gavage once a day. Following seeding, liquid absorption at the injection site, tumor growth (volume and weight), as well as mouse condition, status and survival were observed. Tumor volume was measured on days 5, 7, 12, 16, 19, 21, 25 and 27 post-injection. A concentration of $240 \mathrm{M} / \mathrm{kg}$ was used for subsequent experiments the most prominent effects in tumor growth inhibition. A volume of $100 \mu \mathrm{l}$ of each cell type suspended in PBS $\left(1.0 \times 10^{7} / \mathrm{ml}\right)$ was injected intradermally into the left axilla of the mice. On the following day, mice bearing PDAC cells received $240 \mathrm{M} / \mathrm{kg}$ cordifoliketones A or an equal volume $0.2 \%$ ethanol (noncytotoxic placebo) treatment by gavage once a day. After seeding, liquid absorption at the injection site, tumor growth (volume and weight), and mouse survival were observed. Tumor volume was measured on days $5,7,12,16,19,21,25$ and 27 post-injection. On day 27, all mice were sacrificed, and tumors were isolated for determination of weight and volume (28).

The largest (a) and smallest diameters (b) of each tumor were measured twice on days 5, 7, 12, 16, 19, 21, 25 and 27 to estimate tumor volume $(\mathrm{V})$ using the formula $\mathrm{V}=0.52 \mathrm{x} \mathrm{a}^{2} \mathrm{x} b$ (31). Mean tumor volumes were used to plot tumor growth curves for each group of mice.

Statistical analysis. SPSS v13.0 (SPSS Inc., Chicago, IL, USA) was used for statistical analysis. Data are presented as means \pm standard deviation. One-way analysis of variance with five levels was used with a completely randomized design, and the homogeneity of variance was tested. A q test (Student-Newman-Keuls) was used to compare the differences between groups, and a rank sum test was performed to randomly compare treatments. $\mathrm{P}<0.05$ was considered to indicate a statistically significant difference.

\section{Results}

Cytotoxic of cordifoliketones A on PDAC cells. The cytotoxic abilities against AsPC-1, BxPC-3, PANC-1 and normal human cells by resazurin reduction assay (with doxorubicin as the 

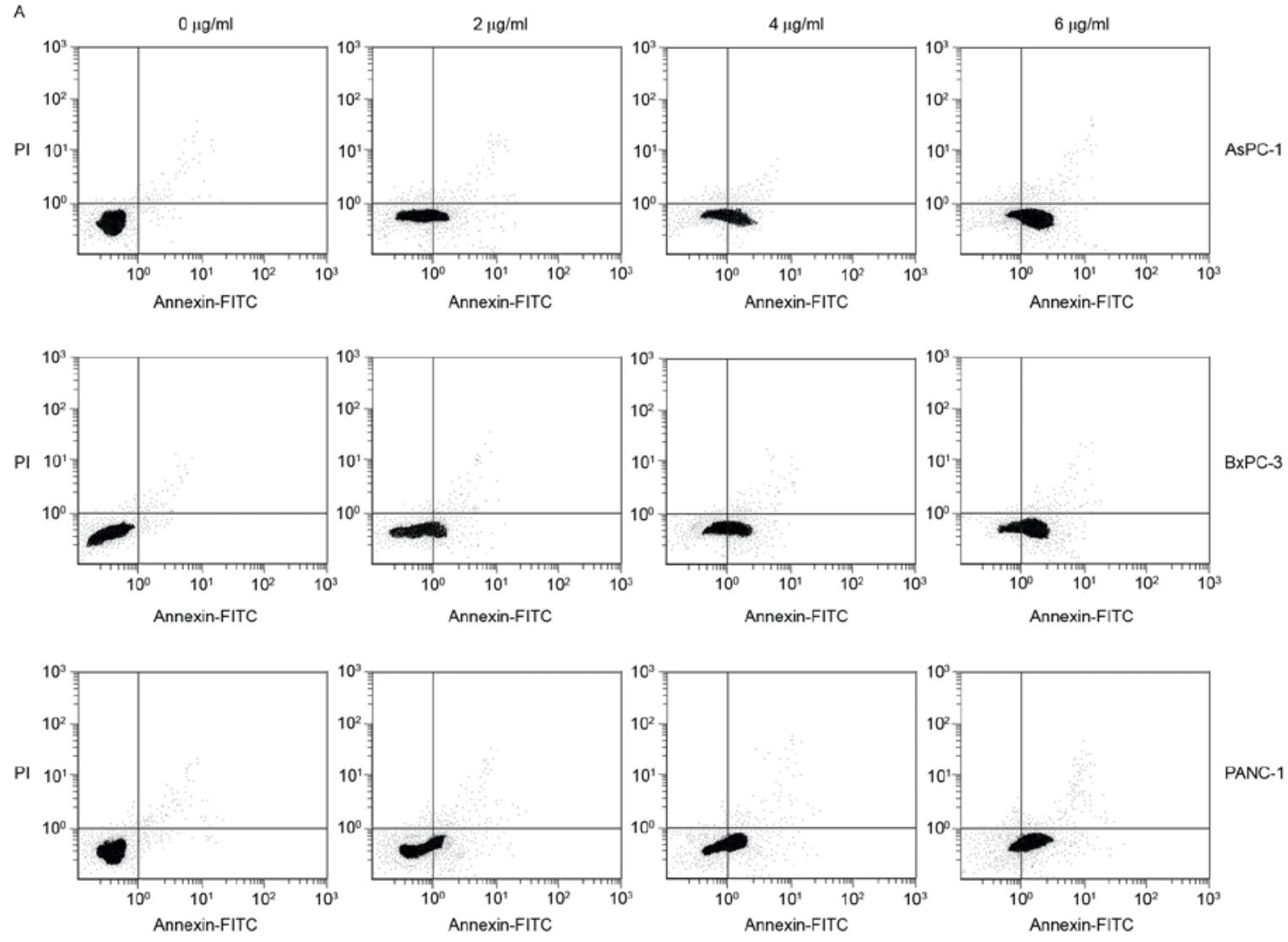

B

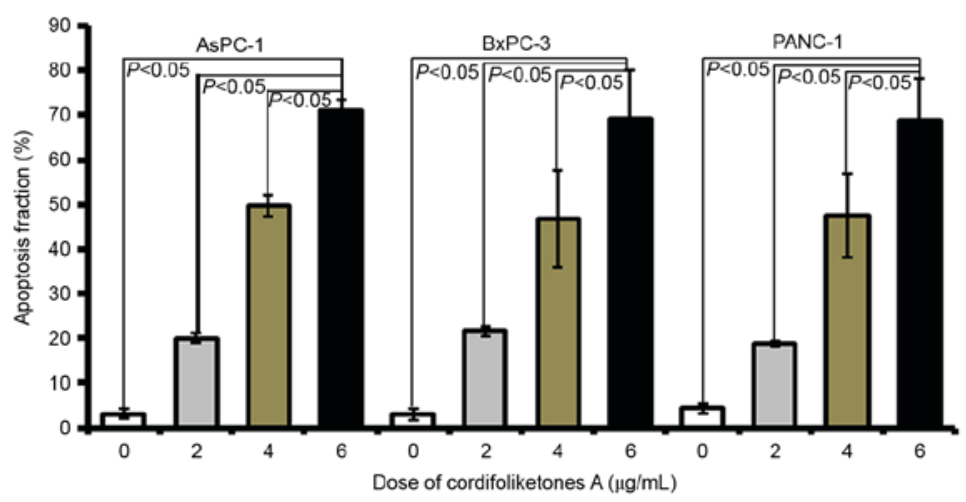

C

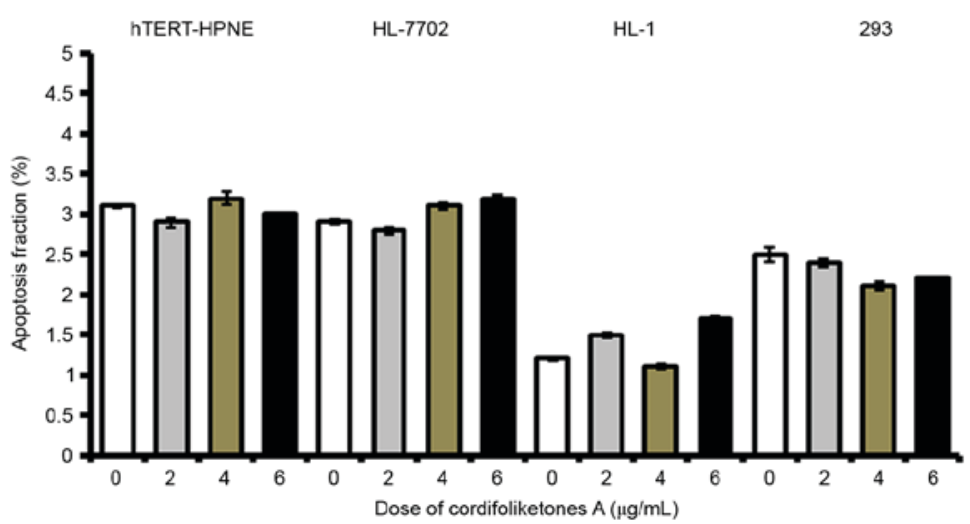

Figure 2. Treatment with cordifoliketones A induces apoptosis in PDAC cells. AsPC-1 cells, BxPC-3, PANC-1 and normal human cells were treated with cordifoliketones A at various doses. (A) The effect of cordifoliketones A (0, 2, 4 and $6 \mu \mathrm{g} / \mathrm{ml})$ on the apoptosis of AsPC-1, BxPC-3 and PANC-1 cells were detected by flow cytometry. (B) Quantification demonstrated that the percentage of apoptotic cells in cordifoliketones A-treated cells was significantly higher compared with the control group $(0 \mu \mathrm{g} / \mathrm{ml})$ in a dose-dependent manner. (C) Cordifoliketones A had no effect on apoptosis in normal human cell lines. Average values are from three independent experiments performed in duplicate. Data are presented as the mean \pm standard deviation ( $\mathrm{n}=3$ ). PDAC, pancreatic ductal adenocarcinoma; FITC, fluorescein isothiocyanate; PI, propidium iodide. 


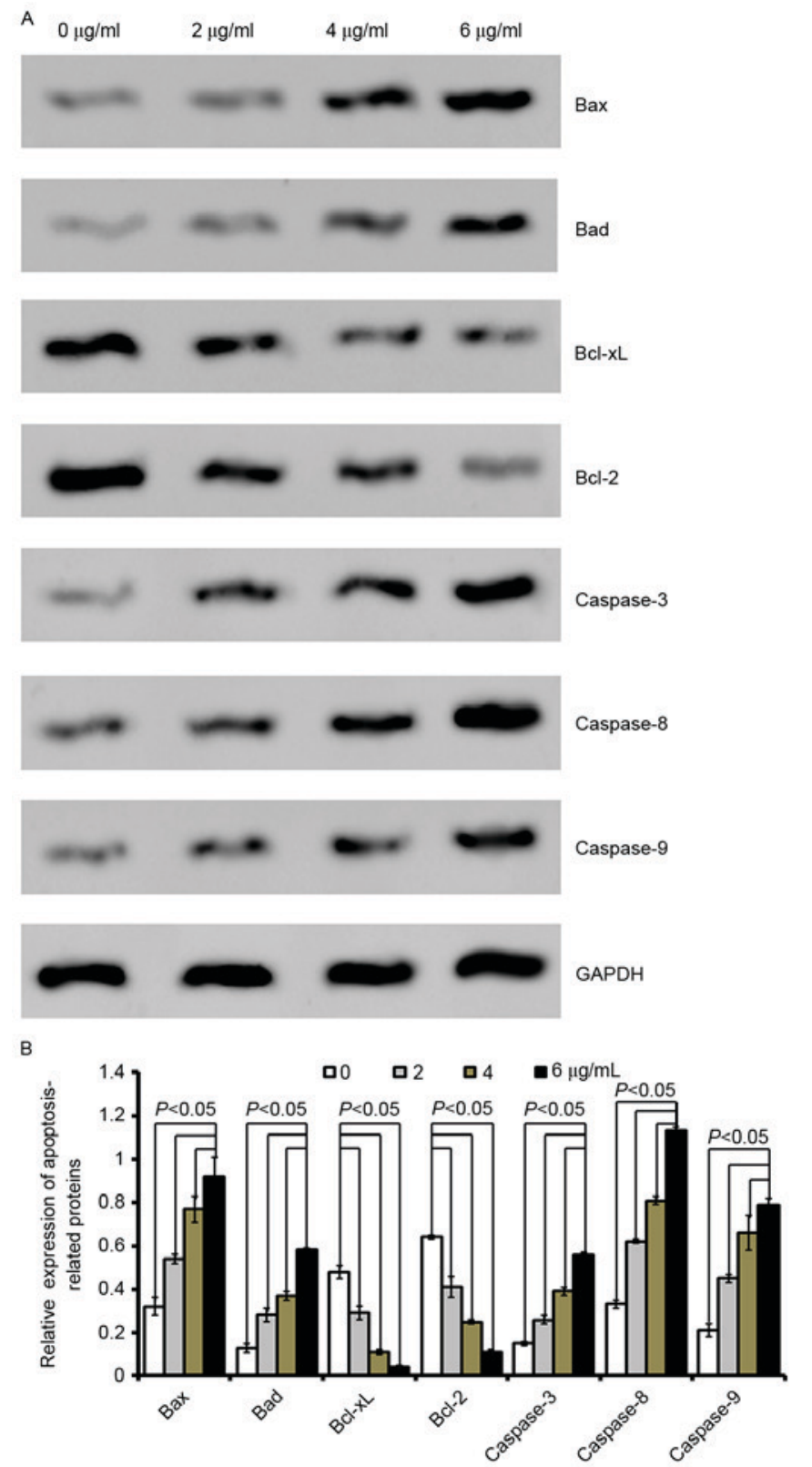

Figure 3. Cordifoliketones A affects the expression of apoptosis-associated proteins in AsPC-1 cells. (A) Representative western blot images and (B) quantification of protein expression levels of Bax, Bad, Bcl-xL, Bcl-2, caspase-3, caspase- 8 and caspase- 9 following cordifoliketones A treatment $(0,2,4$, and $6 \mu \mathrm{g} / \mathrm{ml})$. Average values are from three independent experiments performed in duplicate. Data are presented as the mean \pm standard deviation $(\mathrm{n}=3)$. Bax, Bcl-2-associated X protein; Bad, Bcl-2-associated death promoter; Bcl-XL, B-cell lymphoma extra-large; Bcl-2, B-cell lymphoma 2.

positive control) are presented in Table I. The structure of cordifoliketones A extracted from the roots of $C$. cordifolioidea is presented in Fig. 1A. The results demonstrated that cordifoliketones A has significant potential cytotoxic abilities against various PDAC cell lines in a dose-dependent manner, with $\mathrm{IC}_{50}$ values ranging from 4.18 to $5.56 \mu \mathrm{g} / \mathrm{ml}$ (Table I). The lowest $\mathrm{IC}_{50}$ value of $4.18 \mu \mathrm{g} / \mathrm{ml}$ was obtained by treating PANC-1 cells with cordifoliketones A. Compared to with PDAC cells, normal human hTERT-HPNE cells, and 293, HL-7702 and HL-1 cells were relatively resistant to cordifoliketones A ( $\mathrm{IC}_{50}$ was $>6 \mu \mathrm{g} / \mathrm{ml}$, the highest concentration tested in the study), which implies the specific anticancer activities of cordifoli-
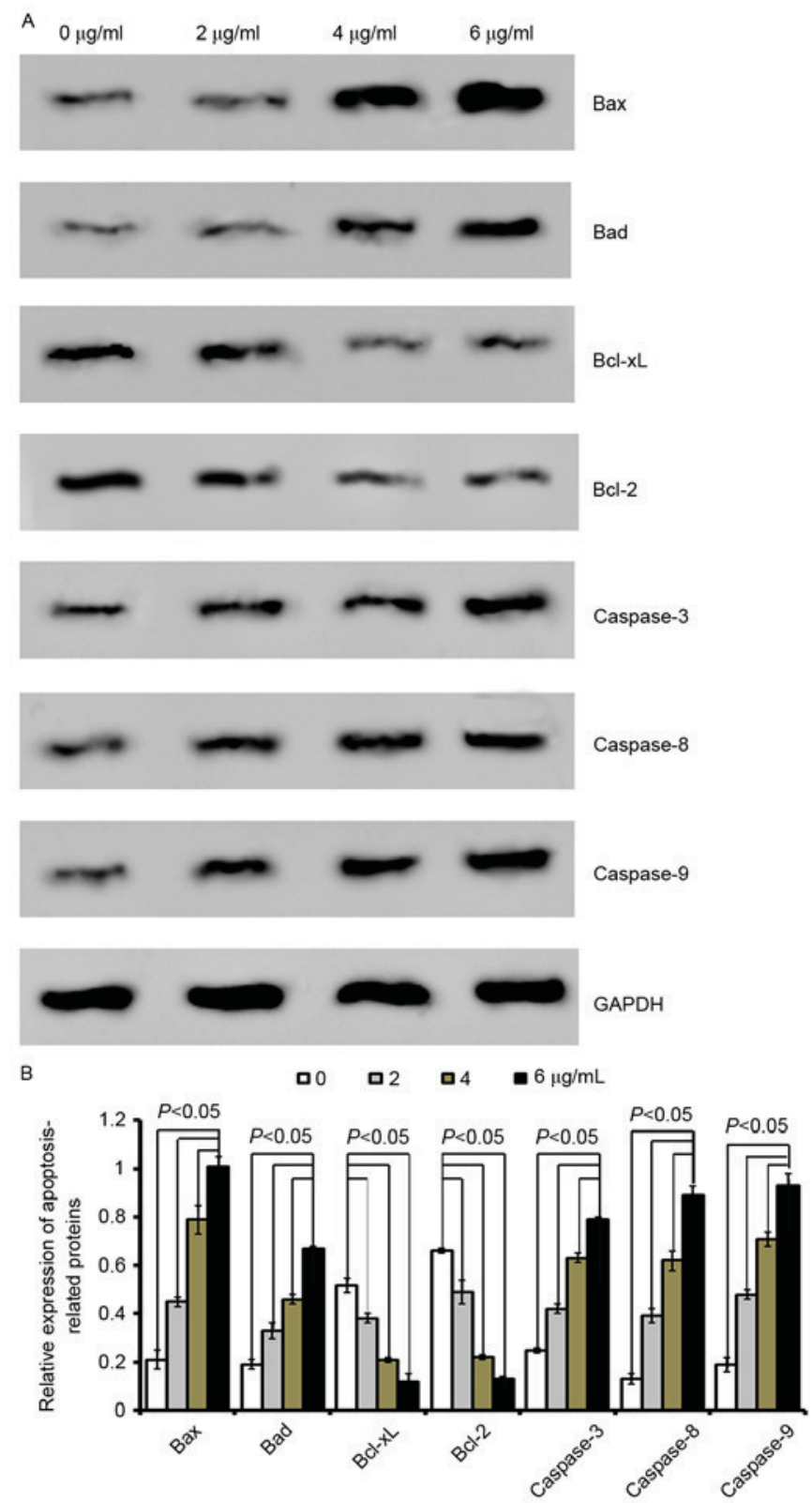

Figure 4. Cordifoliketones A affects the expression of apoptosis-associated proteins in BxPC-3 cells. (A) Representative western blot images and (B) quantification of protein expression levels of Bax, Bad, Bcl-xL, Bcl-2, caspase-3, caspase- 8 and caspase- 9 following cordifoliketones A treatment $(0,2,4$, and $6 \mu \mathrm{g} / \mathrm{ml})$. Average values are from three independent experiments performed in duplicate. Data are presented as the mean \pm standard deviation $(n=3)$. Bax, Bcl-2-associated X protein; Bad, Bcl-2-associated death promoter; Bcl-XL, B-cell lymphoma extra-large; Bcl-2, B-cell lymphoma 2.

ketones A (Fig. 1B and C). Treatment with cordifoliketones A $(>3 \mu \mathrm{g} / \mathrm{ml})$ revealed a significant inhibition in cell viability of PDAC cells. In addition, cordifoliketones A significantly reduced the resazurin fluorescence values from 3-6 $\mu \mathrm{g} / \mathrm{ml}$.

Cordifoliketones A treatment induces apoptosis of PDAC cells. In the three types of PDAC cells, there was a significant increase in the apoptosis rate after treatment with $2 \mu \mathrm{g} / \mathrm{ml}$ cordifoliketones A, compared with $0 \mu \mathrm{g} / \mathrm{ml}$ (blank control; Fig. 2). In AsPC-1, BxPC-3 or PANC-1 cells, cordifoliketones $\mathrm{A}$ increased the apoptosis rate in a dose-dependent manner. There were more apoptotic PDAC cells in the $6 \mu \mathrm{g} / \mathrm{ml}$ 


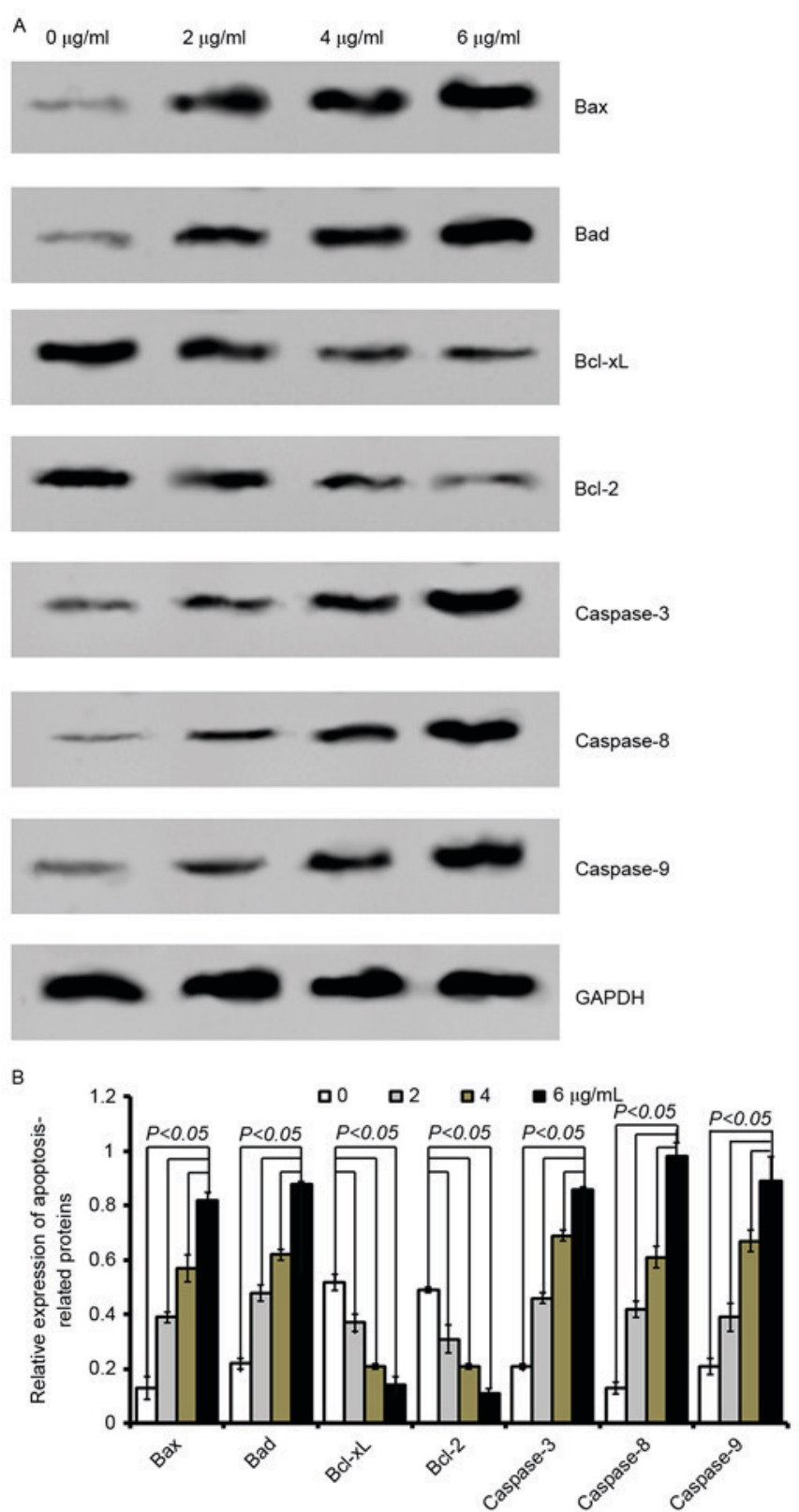

Figure 5. Cordifoliketones A affects the expression of apoptosis-associated proteins in PANC-1 cells. (A) Representative western blot images and (B) quantification of protein expression levels of Bax, Bad, Bcl-xL, Bcl-2, caspase-3, caspase- 8 and caspase-9 following cordifoliketones A treatment $(0,2,4$, and $6 \mu \mathrm{g} / \mathrm{ml})$. Average values are from three independent experiments performed in duplicate. Data are presented as the mean \pm standard deviation $(\mathrm{n}=3)$. Bax, Bcl-2-associated X protein; Bad, Bcl-2-associated death promoter; Bcl-XL, B-cell lymphoma extra-large; Bcl-2, B-cell lymphoma 2.

cordifoliketones A-treated groups, when compared with that the 2 and $4 \mu \mathrm{g} / \mathrm{ml}$ treated groups, respectively (P<0.05, Fig. 2 ). However, cordifoliketones A exhibited no significant effects on the apoptosis of normal human cell lines (Fig. 2C, P>0.05).

Effects of cordifoliketones A on the expression of apoptosis-associated proteins. Quantitative analysis by western blotting demonstrated that cordifoliketones A upregulated the expression of $\mathrm{Bax}$ and $\mathrm{Bad}$, and down-regulated the expression of Bcl-2 and Bcl-xL in AsPC-1 (Fig. 3), BxPC-3 (Fig. 4) and PANC-1 (Fig. 5) cells in a dose-dependent manner $(\mathrm{P}<0.05)$. For the other apoptosis-associated proteins tested, caspase-3/8/9

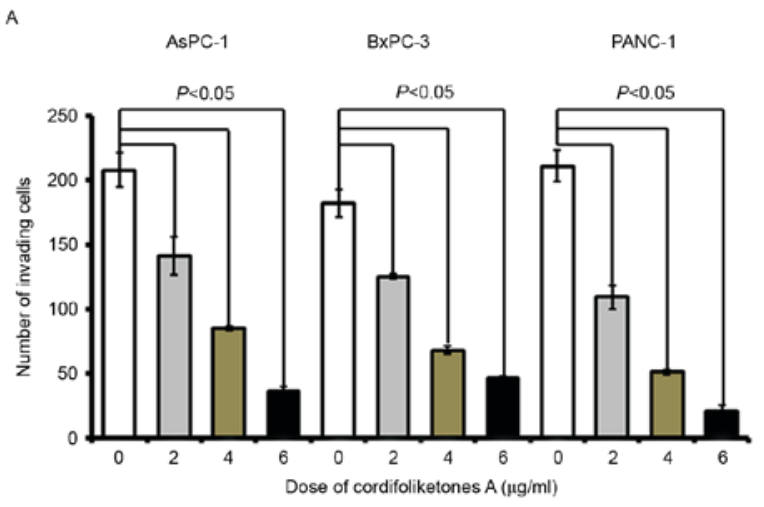

B
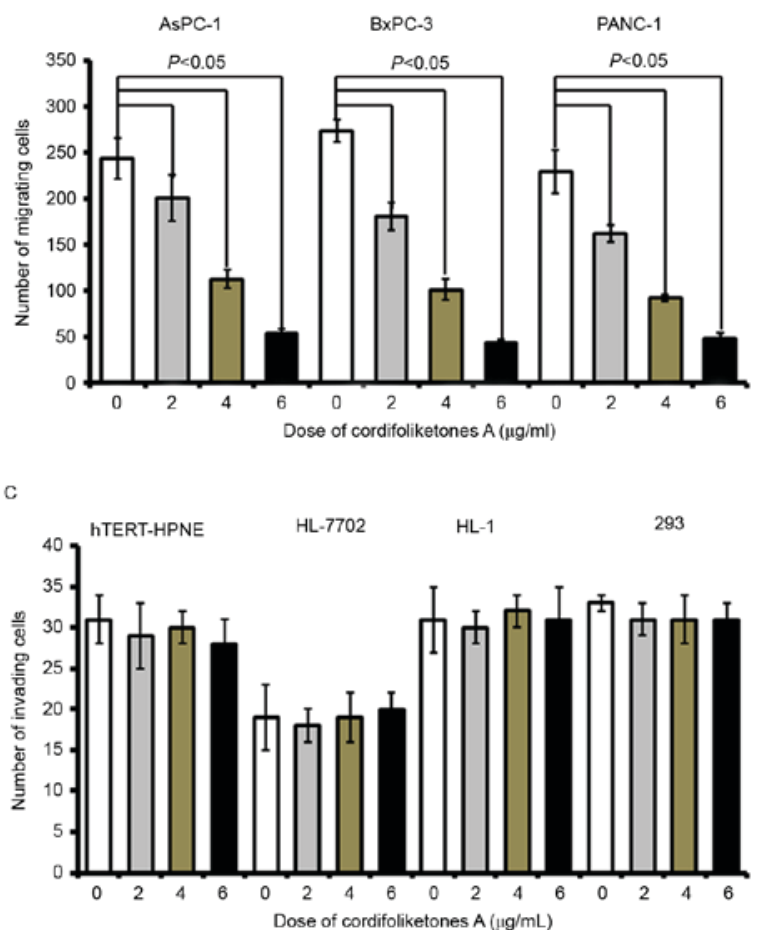

D

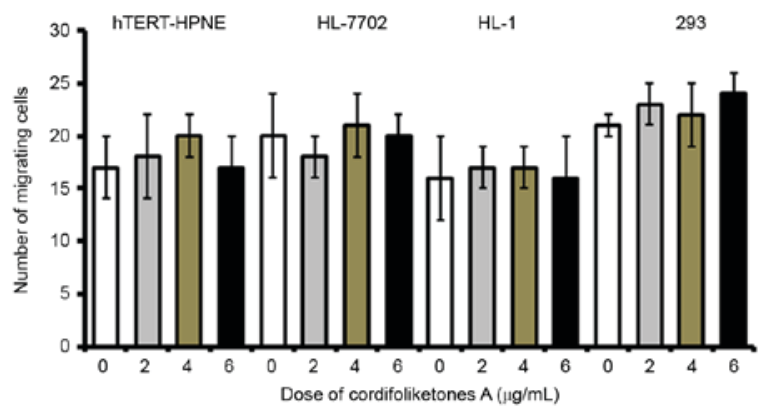

Figure 6. Effects of cordifoliketones A treatment on the migration and invasion of PDAC cell lines and normal human cells. (A) Invasion and (B) migration of PDAC cells. (C) Invasion and (D) migration of normal human cells. Invasion is expressed as number of invading cells per 40x field. Average values are from three independent experiments performed in duplicate. Data are presented as the mean \pm standard deviation $(n=3)$. PDAC, pancreatic ductal adenocarcinoma.

expression were significantly upregulated after treatment with 2, 4 or $6 \mu \mathrm{g} / \mathrm{ml}$ cordifoliketones A in AsPC-1, BxPC-3 and PANC-1 cells ( $\mathrm{P}<0.05$, Figs. 3, 4 and 5, respectively). 

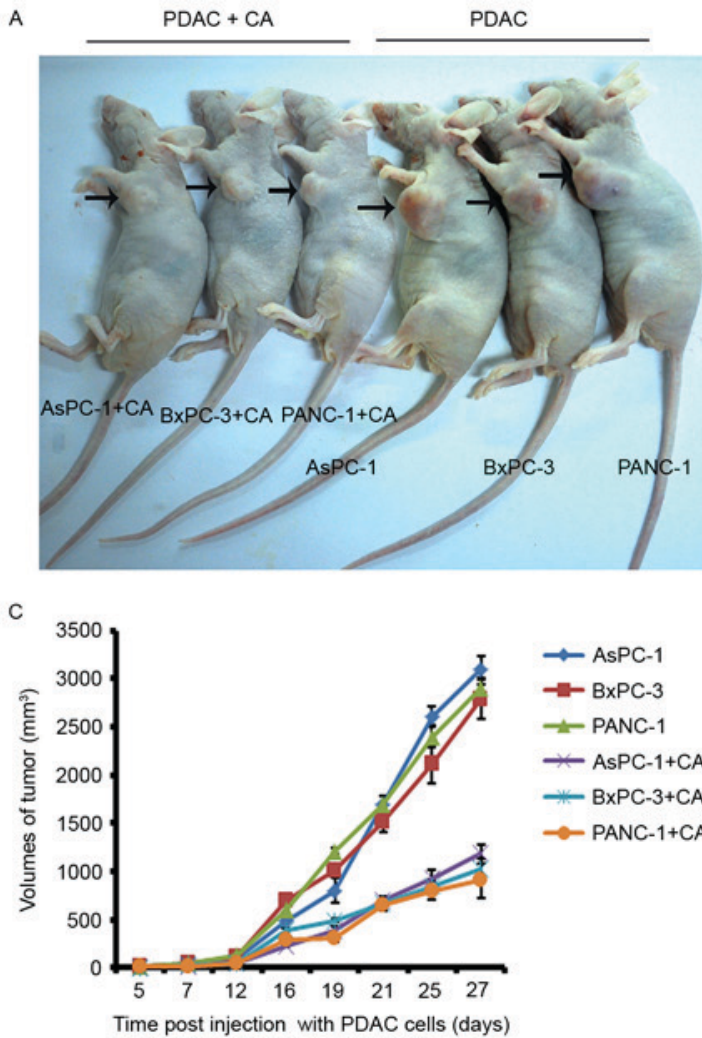

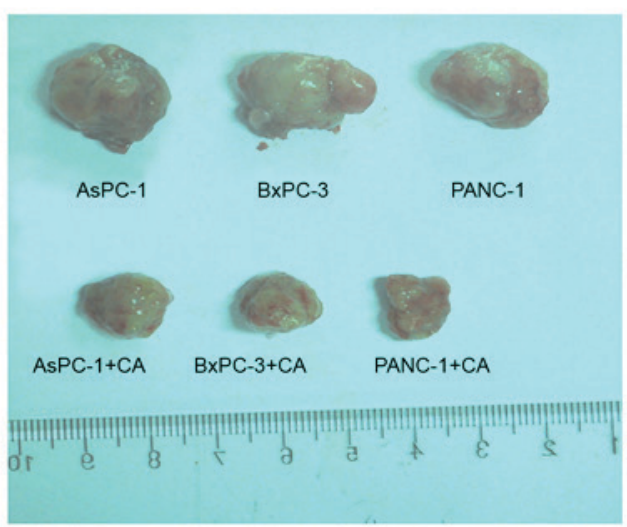

D

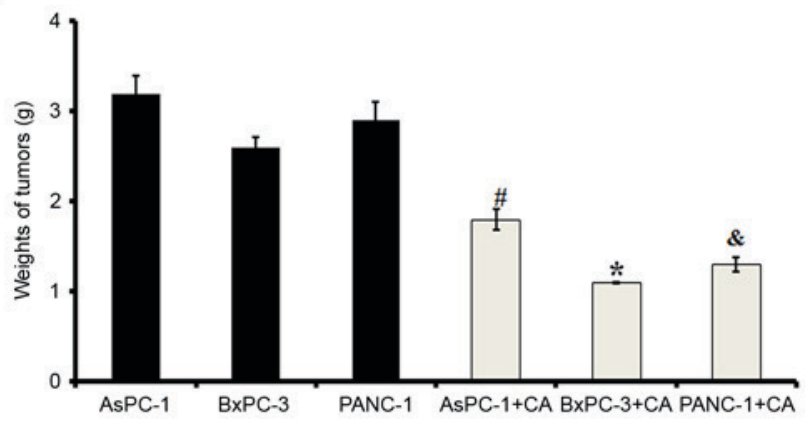

Figure 7. Cordifoliketones A treatment inhibits tumor formation and growth in nude mice. (A) Mice were imaged on day 27. (B) Image of representative tumors. (C) Growth of tumors over 27 days. ${ }^{\#} \mathrm{P}<0.05$ vs. AsPC-1 group; ${ }^{* *} \mathrm{P}<0.05$ vs. BxPC-3 group; ${ }^{*} \mathrm{P}<0.05$ vs. PANC-1 group. (D) Weight of tumors. ${ }^{\#} \mathrm{P}<0.05$ vs. AsPC-1 group; ${ }^{*} \mathrm{P}<0.05$ vs. BxPC-3 group; ${ }^{* *} \mathrm{P}<0.05$ vs. PANC-1 group. Data are presented as the mean \pm standard deviation ( $\left.\mathrm{n}=6\right)$. CA, treatment with cordifoliketones A; PDAC, pancreatic ductal adenocarcinoma.

Cordifoliketones A inhibits migration and invasion of PDAC cells. Following treatment with cordifoliketones A at 2, 4 or $6 \mu \mathrm{g} / \mathrm{ml}$, there were significant reductions in the invasion of AsPC-1, BxPC-3 and PANC-1 cells, in comparison with that of the control cells (treated with $0 \mu \mathrm{g} / \mathrm{ml} ; \mathrm{P}<0.05$; Fig. 6). Furthermore, cordifoliketones A induced inhibitions in migration and invasion of PDAC cells in a dose-dependent manner (Fig. 6).

Cordifoliketones A treatment inhibits the proliferation of $P D A C$ in vivo. To explore the efficacy of cordifoliketones A against PDAC in vivo, the xenograft models were established via subcutaneous injection of cells, and tumor growth was monitored. On day 27 post-injection, mice were sacrificed and the tumors were dissected and weighed. Neoplasms in cordifoliketones A-treated mice grew much more slowly than that in control mice (Fig. 7).

\section{Discussion}

In present study, cordifoliketones A was extracted from the roots of $C$. cordifolioidea, Tsoong. The effects of cordifoliketones A on tumor cell growth, apoptosis, invasion, and migration were examined. The data demonstrated that cordifoliketones A: i) inhibited proliferation and promoted apoptosis of PDAC cells without cytotoxicity against to normal human cells; ii) significantly induced apoptosis and altered expression of apoptosis-associated proteins in a dose-dependent manner; iii) suppressed migration and invasion of PDAC cells in a dose-dependent manner; and iv) restrained the growth of PDAC neoplasms in nude mice. Therefore, these results indicate that cordifoliketones A may be a potential candidate compound for the prevention of PDAC proliferation and metastasis.

Natural products have been used in traditional and folk medicine for therapeutic purposes. They are generally nontoxic compared to synthetic chemical compounds, and thus provide important sources of promising leads for the development of novel therapeutic drugs (30). In this regard, the search for novel chemopreventive and anti-tumor agents that are more effective and less toxic has created a great deal of interest in phytochemicals (30). The roots of $C$. cordifolioidea, locally known as Tsoong, have been used as a food or vegetable and herbal remedies due to their tonic effects in Yunnan Province since ancient times $(17,30)$. Recently, phytochemical research also revealed that the crude extract of Tsoong increased the chemotherapeutic sensitivities, and attenuated and enhance immune function of tumor-bearing mice (31). In light of this, the major components from this plant were isolated and identified. In particular, cordifoliketones A, as one of compounds of the roots of Tsoong, was isolated and demonstrated to have anti-HIV and cytotoxic properties (13). The present study demonstrated that the cytotoxic properties against PDAC cells of cordifoliketones A might be associated with apoptosis promotion and proliferation inhibition.

Disordered apoptosis is important in many disease processes, including oncologic and rheumatologic phenomena, and thus the accurate control of apoptosis is important not just to the normal development of an organism, but also to its health and growth (32). Therefore, various kinds of agents that 
can effectively induce apoptosis offer promising strategies for the treatment of cancer. The present study revealed that treatment with cordifoliketones A significantly induced apoptosis and altered the expression of apoptosis-associated proteins in a dose-dependent manner in PDAC cells. Cordifoliketones A was cytotoxic to AsPC-1, BxPC-3 and PANC-1 cells with an $\mathrm{IC}_{50}$ at most of $5.56 \mu \mathrm{mol} / \mathrm{ml}$ (Table I). This cytotoxicity may be attributable to the induction of apoptosis, as demonstrated by an apoptosis assay and expressional evaluation of proteins associated with apoptosis. The Ced-3/caspase-1 family, which is comprised of caspase-1, caspase-2, caspase-3, caspase-4, caspase- 6 , caspase- 7 , caspase- 9 and caspase- 10 , functions as a key component of apoptosis, and acts to destroy specific target proteins which are critical to cellular longevity (33). As an initiator caspase, caspase- 8 activates effector caspases by cleaving their inactive forms. In the activation cascade responsible for apoptosis induced by tumor necrosis factor receptor superfamily member $1 \mathrm{~A}$ and mediated by tumor necrosis factor receptor superfamily member 6 , caspase- 8 is the most upstream protease. B-cell lymphoma 2 (Bcl-2) among numerous key regulators of apoptosis, are essential for development, tissue homeostasis and protection against foreign pathogens. Human Bcl-2 is an anti-apoptotic, membrane-associated oncoprotein that can promote cell survival via protein-protein interactions with other Bcl-2-associated family members, such as the death suppressors B-cell lymphoma extra-large (Bcl-xL), induced myeloid leukemia cell differentiation protein (MCL-1), Bcl-2-like protein 2 and $\mathrm{A} 1$, or the death agonists $\mathrm{Bcl}-2$-associated $\mathrm{X}$ protein (Bax), Bcl-2 homologous antagonist/kiler, Bcl-2 interacting killer, Bcl-2-associated death promoter (Bad) and $\mathrm{BH} 3$-interacting domain death agonist $(33,34)$.

Cordifoliketones A upregulated the expression of Bax, Bad and caspase-3/8/9, and downregulated the expression of $\mathrm{Bcl}-2$ and Bcl-xL. As a complex biochemistry process, apoptosis is regulated by a variety of factors $(35,36)$. The two most important groups of proteins involved in apoptotic cell death has been demonstrated as members of the Bcl-2 family and caspases $(37,38)$. It is well known that the Bcl-2 family functions as inhibitors (e.g. Bcl-2, Bcl-xL and MCL-1) or promoting factors (e.g. Bax, Bcl-XS, Bad and Bak) in programmed cell death, apoptosis. Otherwise, subsequent activation of caspase-3 has been regarded as a primary mechanism of apoptosis $(38,39)$. Given this knowledge, it was hypothesized that cytotoxic properties against PDAC cells of cordifoliketones A might be associated with induction apoptosis. Additionally, chemical agents with strong apoptosis-inducing activity but minimal toxicity are expected to have potential utility as anticancer drugs $(22,40)$. The present study additionally revealed that cordifoliketones A exhibited no cytotoxicity to normal hTERT-HPNE cells, which suggested that cordifoliketones A might be a promising anticancer drug against PDAC. Furthermore, the present data also demonstrated that cordifoliketones A treatment cells inhibited the migration and invasion of PDAC cells in a dose-dependent manner. Therefore, the results indicated that cordifoliketones A might prevent of PDAC metastasis by inhibiting in invasion and migration.

Taking together, these results indicate that cordifoliketones A may be a potential candidate compound for the prevention of PDAC proliferation and metastasis, presumably by induction apoptosis, inhibiting proliferation, invasion and migration of PDAC cells, as well as minimal toxicity to normal cells. However, the mechanisms underlying remain unknown and require further investigation.

In conclusion, the present study demonstrated that cordifoliketones A prepared from the roots of $C$. cordifolioidea, Tsoong: i) inhibited proliferation and promoted apoptosis of PDAC cells; ii) significantly induced apoptosis and altered expression of apoptosis related protein in a dose-dependent manner; iii) suppressed migration and invasion of PDAC cells in a dose-dependent manner; and iv) restrained the growth of PDAC neoplasm in nude mouse. Furthermore, cordifoliketones A exhibited non-cytotoxic activity in normal human cells. Therefore, these results indicated that cordifoliketones A may be a potential candidate compound for the prevention of PDAC proliferation and metastasis, presumably by induction of apoptosis, and inhibiting invasion and migration of PDAC cells.

\section{Acknowledgements}

The present study was supported by Yunnan Provincial Department of Education (grant no. 2015Y288).

\section{References}

1. Stathis A and Moore MJ: Advanced pancreatic carcinoma: Current treatment and future challenges. Nat Rev Clin Oncol 7: $163-172,2010$.

2. Hariharan D, Saied A and Kocher HM: Analysis of mortality rates for gallbladder cancer across the world. HPB (Oxford) 10: 327-331, 2008.

3. Jiang SH, He P, Ma MZ, Wang Y, Li RK, Fang F, Fu Y, Tian GA, Qin WX and Zhang ZG: PNMA1 promotes cell growth in human pancreatic ductal adenocarcinoma. Int J Clin Exp Pathol 7: 3827-3835, 2014.

4. Siegel R, Ma J, Zou Z and Jemal A: Cancer statistics. CA Cancer J Clin 64: 9-29, 2014.

5. Conroy T, Desseigne F, Ychou M, Bouché O, Guimbaud R, Bécouarn Y, Adenis A, Raoul JL, Gourgou-Bourgade S, de la Fouchardière $\mathrm{C}$, et al: FOLFIRINOX versus gemcitabine for metastatic pancreatic cancer. N Engl J Med 364: 1817-1825, 2011.

6. Siegel RL, Miller KD and Jemal A: Cancer statistics. CA Cancer J Clin 65: 5-29, 2015.

7. Molejon MI, Tellechea JI, Moutardier V, Gasmi M, Ouaissi M, Turrini O, Delpero JR, Dusetti N and Iovanna J: Targeting CD44 as a novel therapeutic approach for treating pancreatic cancer recurrence. Oncoscience 2: 572-575, 2015.

8. Zhang W, Yao JL, Dong SC, Hou FQ and Shi HP: SLPI knockdown induced pancreatic ductal adenocarcinoma cells proliferation and invasion. Cancer Cell Int 15: 37, 2015.

9. Lee YJ, Kim DB, Lee JS, Cho JH, Kim BK, Choi HS, Lee BY and Lee OH: Antioxidant activity and anti-adipogenic effects of wild herbs mainly cultivated in Korea. Molecules 18: 12937-12950, 2013.

10. Xin T, Zhang F, Jiang Q, Chen C, Huang D, Li Y, Shen W, Jin Y and Sui G: The inhibitory effect of a polysaccharide from Codonopsis pilosula on tumor growth and metastasis in vitro. Int J Biol Macromol 51: 788-793, 2012.

11. Shin JA, Kim JS, Hong IS and Cho SD: Bak is a key molecule in apoptosis induced by methanol extracts ofCodonopsis lanceolata and Tricholoma matsutake in HSC-2 human oral cancer cells. Oncol Lett 4: 1379-1383, 2012.

12. Huo J, Qin F, Cai X, Ju J, Hu C, Wang Z, Lu W, Wang X and Cao P: Chinese medicine formula 'Weikang Keli' induces autophagic cell death on human gastric cancer cell line SGC-7901. Phytomedicine 20: 159-165, 2013.

13. Hu QF, Xuesen Li XS, Huang HT, Mu HX, Tu PF and Li GP: Phenylpropanoids from the roots of codonopsis cordifolioidea and their biological activities. Bull Korean Chem Soc 33: 278-280, 2012.

14. Hong DY, Lian YS and Shen LD: Flora of China. Science Press: Beijing 73: 32, 1983. 
15. Yunnan Corporation of Materia Medica, List of Chinese Herb Medicine Resources in Yunnan. Science Publishing 544, 1993.

16. Duang QF, Zhao H and Wang YQ: The cytotoxicity of Nature medicine in Yunnan province. Chin J Yunnan Med 12: 39, 2003.

17. Chen ZJ, Wei QH and Zhou JY: The effects of Codonopis bulleynana on the growth and proliferation of HL60 cells. Yunnan J Tradit Chin Med Mater. 27: 49, 2006.

18. Sun J, Wang L, Wang M, Wang Z and Li F: Two new polyacetylene glycosides from the roots of Codonopsis tangshen Oliv. Nat Prod Res. 30: 2338-2343, 2016

19. Chen ZJ, Wei QH and Zhou JY: The research development in Tsoong. Yunnan J Tradit Chin Med Mater 27: 49-50, 2006.

20. Luan YP, Zheng SQ and Li YM: Identification of active ingredient of codonopsis cordifolioidea by n-butyl alcohol. Adv Eng Res. 178-182, 2016.

21. Li C, Ni J, Liu YX, Wang H, Liang ZQ and Wang X: Response of MiRNA-22-3p and MiRNA-149-5p to Folate Deficiency and the Differential Regulation of MTHFR Expression in Normal and Cancerous Human Hepatocytes. PLoS One 12: e0168049, 2017.

22. Lee KW, Jung HJ, Park HJ, Kim DG, Lee JY and Lee KT: Beta-D -xylopyranosyl-( $(\rightarrow 3)$-beta-D-glucuronopyranosyl echinocystic acid isolated from the roots of Codonopsis lanceolata induces caspase-dependent apoptosis in human acute promyelocytic leukemia HL-60 cells. Biol Pharm Bull 28: 854-859, 2005.

23. Kuete V, Fankam AG, Wiench B and Efferth T: Cytotoxicity and modes of action of the methanol extracts of six Cameroonian medicinal plants against multidrug-resistant tumor cells. Evid Based Complement Alternat Med 2013: 85903, 2013.

24. Kuete V, Tankeo SB, Saeed ME, Wiench B, Tane P and Efferth T: Cytotoxicity and modes of action of five Cameroonian medicinal plants against multi-factorial drug resistance of tumor cells. J Ethnopharmacol 153: 207-219, 2014

25. Kuete V, Sandjo LP, Mbaveng AT, Seukep JA, Ngadjui BT and Efferth T: Cytotoxicity of selected Cameroonian medicinal plants and Nauclea pobeguinii towards multi-factorial drug-resistant cancer cells. BMC Complement Altern Med 15: 309, 2015.

26. Skup M, Dwornik A, Macias M, Suleczak D, Wiater M and Czarkoeska-Bauch J: Long-term locomotor training upregulates TrkBFL receptor-like proteins, brain-derived neurotrophic factor, and neurotrophin 4 with different topographies of expression in oligodendroglia and neurons in the spinal cord. Exp Neurol 176 289-307, 2002
27. Qin DX, Zou XL, Luo W, Zhang W, Zhang HT, Li XL, Zhang H, Wang XY and Wang TH: Expression of some neurotrophins in the spinal motoneurons after cord hemisection in adult rats. Neurosci Lett 410: 222-227, 2006.

28. Hu T, Zhang C, Tang Q, Su Y, Li B, Chen L, Zhang Z, Cai T and Zhu Y: Variant G6PD levels promote tumor cell proliferation or apoptosis via the STAT3/5 pathway in the human melanoma xenograft mouse model. BMC Cancer 13: 251, 2013.

29. Niu G, Heller R, Catlett-Falcone R, Coppola D, Jaroszeski M, Dalton W, Jove R and Yu H: Gene therapy with dominant-negative Stat 3 suppresses growth of the murine melanoma B16 tumor in vivo. Cancer Res 59: 5059-5063, 1999.

30. Wang L, Xu ML, Hu JH, Rasmussen SK and Wang MH: Codonopsis lanceolata extract induces G0/G1 arrest and apoptosis in human colon tumor HT-29 cells-involvement of ROS generation and polyamine depletion. Food Chem Toxicol 49: 149-154, 2011

31. Wu ZY: Herbal in Yunnan. Science Press: Beijing 5: 487, 1991.

32. Chen ZJ, Li YS, Wei QH, Chen SL and Chen DX: Efects of Codonopis bulleynana Forest ex Diels on enhancing sensitivity, reducing toxicity of chemotherapy and regulating immune function in Sarcoma 180 tumor-bearing mice. Chin Trad Patent Med 34: 1848-1851, 2012.

33. Kerr JF, Wyllie AH and Currie AR: Apoptosis: A basic biological phenomenon with wide-ranging implications in tissue kinetics. Br J Cancer 26: 239-257, 1972

34. Hockenbery D, Nuñez G, Milliman C, Schreiber RD and Korsmeyer SJ: Bcl-2 is an inner mitochondrial membrane protein that blocks programmed cell death. Nature 22: 334-336, 1990.

35. Vaux D and Korsmeyer S: Cell death in development. Cell 96: 245-254, 1999

36. Adams JM and Cory S: The Bcl-2 protein family: arbiters of cell survival. Science 281: 1322-1326, 1998.

37. Qiang FX and Guo YJ: Apoptosis in oncology. Cell Res 11: 1-7, 2001.

38. Korsmeyer SJ: BCL-2 gene family and the regulation of programmed cell death. Cancer Res 59: 1693-1700, 1999.

39. Cohen GM: Caspases: The executioners of apoptosis. Biochem. J 326: 1-16, 1997.

40. Nagata S: Apoptosis by death factor. Cell 88: 355-365, 1997.
This work is licensed under a Creative Commons Attribution-NonCommercial-NoDerivatives 4.0 International (CC BY-NC-ND 4.0) License. 